DOI 10.17816/transsyst201843s1134-155

\author{
(c) E. Fritz' , J. Klühspies ${ }^{2}$, R. Kircher ${ }^{2}$, M. Witt ${ }^{2}$, L. Blow ${ }^{3}$ \\ ${ }^{1}$ IfB - Institut für Bahntechnik \\ (Dresden, Germany) \\ ${ }^{2}$ The International Maglev Board \\ ${ }^{3}$ Maglev Transport consulting group \\ (Arlington, USA)
}

\title{
ENERGY CONSUMPTION OF TRACK-BASED HIGH-SPEED TRAINS: MAGLEV SYSTEMS IN COMPARISON WITH WHEEL-RAIL SYSTEMS
}

Background: The energy consumption of a high-speed system is an important part of its total operational costs. This paper compares the secondary energy demand of different wheel-rail systems, such as ICE, TGV and Shinkansen, and maglev systems, such as Transrapid and Chuo Shinkansen.

In the past, energy values of systems with different conditions (train configuration, dimension, capacity, maximum speed) were frequently compared. The comparative values were often represented by the specific energy consumption based on passenger capacity and line-kilometer values.

Aim: The goal is to find a way to compare the specific energy consumption of different high-speed systems without any distortion of results.

Methods: A comparison of energy values based on normative usable areas inside the high-speed systems will be described and evaluated in this paper, transforming the results to a more distortion-free comparison of energy consumption of different systems.

Results: The results show the energy consumption as an important characteristic parameter of high-speed transportation systems based on an objective comparison and give ranges of expected energy demand of different systems dependent on maximum speed level.

Conclusion: Up to the design speed of wheel-rail systems there are slight advantages in terms of energy consumption for the Transrapid maglev. From the perspective of energy consumption under consideration to reduce travel time, high-speed maglev systems represent a promising option for new railway projects. However, a project-specific system decision must be based on a complete life-cycle cost analysis, including investment cost.

Keywords: Energy consumption, maglev system, high-speed trains, wheel-rail systems, specific energy consumption, Transrapid, Chuo Shinkansen, ICE, TGV

\section{INTRODUCTION}

Energy consumption is an important criterion of the operating costs when comparing the operational features of modern High-Speed railway (HSR) systems for 
long-distance services. This article presents and compares the energy consumption of selected HSR systems based either on magnetic levitation and long stator motor technology (Maglev systems) or on wheel-on-rail technology (R/S systems).

\subsection{Objective and focus of the research}

The purpose of the study is to achieve an objective and comparative representation of the energy consumptions for the High-Speed railway systems available in the market. Various railway systems have been compared in the past mostly based on different fundamentals (so-called distorted comparisons), that is, the energy consumption values for vehicles of different lengths, widths and speeds were compared without retroactive calculation on a standardised basis. This study aims to achieve a view that can enable a better result in terms of objectivity.

The focus of the research can be stated as follows:

How much energy, differentiated by speed, is required for a train with a normalised effective area, when it is driven by a certain High-Speed railway system, R/S system (TGV, ICE, Shinkansen) or Maglev (Transrapid, Chuo-Maglev)?

The statements relate to the requirement of secondary energy. This includes the actual traction energy consumption as well as the energy consumption for auxiliary systems (such as for support and guidance, lighting and air-conditioning) on board the vehicles. The generation of primary energy, i.e., the underlying primary energy sources, as well as their specific efficiency chains, are not considered in this comparison because these factors depend on country and operator-specific conditions and it is not possible to generalise.

In addition to operating costs (such as maintenance, operating personnel, insurance, operating and marketing), operational performance aspects also have to be compared. Such factors include designed speed, travel time (between stations), transport capacity and train frequency, and, for system decision in the case of a specific project, a comprehensive life cycle-cost analysis, including the investment costs associated with the power supply infrastructure. These additional system aspects are not included in this study, which is confined to the operational aspects of energy consumption.

\subsection{Relevance}

The topic becomes relevant again especially due to developments in Japan and in the United States of America, where the construction and operation of the Japanese Maglev system L0 has become a concrete topic. A High-Speed Maglev 
line is already being constructed between Tokyo and Nagoya in Japan, with an estimated investment of approximately 50 billion $€$ (US $\$ 62$ billion) for the infrastructure. The construction of the same Japanese Maglev system to connect Baltimore and Washington is already in an advanced stage of planning.

\section{DATA SOURCES AND COMPARISON CRITERIA}

Systems which have been in trial and operational for many years and for which the most possible reliable data is available were selected for the comparative study of energy consumption. This is true for the selected Wheel-Rail systems of Shinkansen, ICE and TGV, as well as the Maglev system Transrapid.

\subsection{Selection of the railway systems to evaluate and the information basis}

The German ICE 3 was chosen due to the solid data availability, even though other developed versions, such as the Spanish Velaro E or the Chinese CRH380A, are in operation. The latest ICE 4 system of DB AG, although it is more modern than the ICE 3 on the whole, was not included in the comparison because the ICE 4 is not completely suitable due to its top speed limit of just $250 \mathrm{~km} / \mathrm{h}$.

For the Japanese Maglev system Chuo Shinkansen (Maglev L0), the information from a scientific point of view appears to be remarkably slight, although the first stage of the project, a 290-km-line between Tokyo and Nagoya, is already being constructed. A comprehensive technical data fact sheet for the Maglev L0 is so far not available despite the advanced stage of implementation. Hardly any technical specifications are officially available due to the restrictive information-sharing policy of the project leader, Central Japan Railway (JR Central). Partial information can be obtained about the project from other Japanese sources, which, although technically sound, can be mainly attributed to the critics of the Maglev L0 based on the respective arguments. Some information is also available in official letters from the Japanese government or ministries. Other indications can be found occasionally (but not verifiably) in Japanese newspapers and railway magazines.

Because the Maglev L0 is an ongoing project with high market impact, a study which did not try to include the Chuo Shinkansen would make little sense. The following information and calculations pertaining to the Chuo Shinkansen were compiled from several, mainly Japanese, sources $[1,2,3]$, and by associating the data referred in them with the few available official statements. By making a comparison with at least the rough data of the previous MLX vehicle, verification 
can be made in principle as to whether the representation for the Maglev L0, which is based on the same technical system principles, can be regarded as realistic.

\subsection{Basis of energy consumption calculation}

In principle, the specific energy consumption values for a railway system depend on the technical system design, the maximum speed, and the train configuration for the different application cases. The main reasons for the energy consumption values which are to some extent quite different include:

- the different line characteristics, topography,

- the considered clearance,

- the different train configurations of the railway systems being considered,

- specific operator requirements in terms of fittings (number of seats and comfort), aisle width, luggage storage space and restaurant service, and therefore the maximum total seating capacity,

- the design of the traction system and power supply, particularly in the Maglev systems,

- the different vehicle lengths (which impact driving resistance, vehicle weight),

- the respective operational design speed, and

- number of stations and distance between stations.

The data of the Wheel-Rail systems considered here are shown for $300 \mathrm{~km} / \mathrm{h}$ (N 700) and $330 \mathrm{~km} / \mathrm{h}$ (ICE 3 ). Therefore, the energy can be directly compared among the Wheel-Rail systems and Maglev systems only for this speed range. By including the Velaro E (RENFE series 103) or Velaro CN based on the ICE 3, as well as the Chinese CRH 380A, a comparison at higher speeds up to a maximum of $380 \mathrm{~km} / \mathrm{h}$ would be possible. Higher speeds of up to $550 \mathrm{~km} / \mathrm{h}$ in normal operation appear feasible only with Maglev systems based on the long stator drive system.

In the following study, the specific energy consumption for the systems are compared based on the two parameters $\mathrm{Wh} / \mathrm{Pl} / \mathrm{km}$ (conventional representation, according to number of seats) and $\mathrm{Wh} / \mathrm{m}^{2} / \mathrm{km}$ (new, according to surface area, as discussed in section 5).

\subsection{Overview of key figures of the selected railway systems}

The following railway systems for High-Speed long-distance services were selected for comparison:

- Wheel-Rail systems:

- ICE 3 (Germany) 
- TGV Duplex Dasye (France)

- Shinkansen N 700 (Japan)

- MAGLEV systems

- Transrapid 08 (Germany/China; electromagnetic system - supporting and guiding systems based on attraction - coupled with longstator linear motor)

- Chuo Shinkansen Maglev L0 (Japan; differential flow system for support, guidance and propulsion with 8-shaped coils in the track side walls and superconducting magnets in the vehicle)

Table 1. Data relevant for comparing High-Speed railway systems

\begin{tabular}{|c|c|c|c|c|c|}
\hline & $\begin{array}{c}\text { ICE3 } \\
\text { (Velaro D) } \\
{[4]}\end{array}$ & $\begin{array}{c}\text { Shinkansen } \\
\text { N700 } \\
(7000-8000) \\
{[5,6,7]}\end{array}$ & $\begin{array}{c}\text { TGV } \\
\text { Duplex } \\
\text { Dasye } \\
{[8]}\end{array}$ & $\begin{array}{c}\text { Transrapid } \\
\text { TR } 08 \\
\text { [9] }\end{array}$ & $\begin{array}{c}\text { Chuo } \\
\text { Shinkansen } \\
{[1,2,3]}\end{array}$ \\
\hline $\begin{array}{l}\text { Number of cars/ } \\
\text { sections }\end{array}$ & 8 & 8 & 10 & $4 / 5$ & 3 to 12 \\
\hline Number of motors & 16 & 32 & 8 & Linear motor & Linear motor \\
\hline Drive power $(\mathrm{kW})$ & $16 \times 500$ & $32 \times 305$ & $8 \times 1160$ & $\begin{array}{l}\text { Depends on } \\
\text { the project }\end{array}$ & $\begin{array}{l}\text { Depends on } \\
\text { the project }\end{array}$ \\
\hline Unloaded weight (t) & 455 & 356 & 380 & $226 / 282$ & 300 \\
\hline Seats (total) & 460 & $522+24$ & 510 & $360 / 446$ & 106 to 704 \\
\hline Length 1 (m) & 200.7 & 204.7 & 200.2 & $100.5 / 125.3$ & 80 to 299 \\
\hline Width w (m) & 2.92 & 3.36 & 2.90 & 3.70 & 2,90 \\
\hline $\begin{array}{l}\text { Basic area in } \mathrm{m}^{2} \\
(\text { for computation } \\
1 * \mathrm{w})\end{array}$ & 586 & 688 & 581 & $372 / 464$ & 233 to 867 \\
\hline $\begin{array}{l}\text { Effective area in } \\
\mathrm{m}^{2} \text { (basic area } \\
\text { minus areas used by } \\
\text { system) }\end{array}$ & $\begin{array}{c}538 \\
\text { see chap. } 5\end{array}$ & $\begin{array}{c}627 \\
\text { see chap. } 5\end{array}$ & $\begin{array}{c}533 \\
\text { see chap. } 5\end{array}$ & $\begin{array}{c}331 / 423 \\
\text { see chap. } 5\end{array}$ & $\begin{array}{l}156 \text { to } 660 \\
\text { see chap. } 5\end{array}$ \\
\hline $\begin{array}{l}\text { Maximum speed } \\
(\mathrm{km} / \mathrm{h})\end{array}$ & 330 & 300 & 320 & $\begin{array}{c}500 \\
\text { Depending } \\
\text { on project }\end{array}$ & $\begin{array}{c}550 \\
\text { Depending } \\
\text { on project }\end{array}$ \\
\hline
\end{tabular}

For future applications, it must be recognised that both wheel-on-rail technology and Maglev systems have further potential for development. This applies to Wheel-Rail systems with regard to the efficiency of their drive system, and to Maglev systems with regard to the efficiency of the drives and to power transmission, energy supply and control. Such development potentials are not taken into account in this study so as not to allow for speculative assumptions. 


\subsection{Selection of potential application routes}

This comparison of energy consumption values is based on the following potential application routes:

- Berlin - Hamburg, approx. 290 km, 3 stops, railway systems considered: Transrapid, ICE 3 [10];

- Berlin - Budapest, approx. 900 km, 8 stops, railway systems considered: Transrapid, ICE 3 [11];

- Leipzig - Dresden, approx. $110 \mathrm{~km}$ without stops, railway systems considered: MLX (predecessor of Chuo Shinkansen L0), Transrapid, ICE 3, [9]. Here, the Japanese Maglev system MLX is operated on an open-air, above-ground section, in contrast to the current Chuo Shinkansen system, for which operation is planned almost exclusively in tunnels during its first commercial application. Data are available only for tunnel sections for the current Chuo Shinkansen system. These values may be updated with current vehicle and route data from a JR Central source, but so far no recent publications are available;

- Rio de Janeiro - Campinas, approx. 510 km, 6 stops, railway systems considered: Transrapid, ICE 3 [12];

- Zuiderzeelijn (Netherlands), about $180 \mathrm{~km}, 8$ stops, railway system considered: Transrapid [13];

- Rhine - Rhone, $140 \mathrm{~km}, 2$ stops, railway system considered: TGV [8].

Only energy consumption values for so-called cruising in the tunnel are available for the current Japanese Maglev system Chuo Shinkansen [1]. An average energy consumption value on the Tokaido HSR line [14], as well as some energy consumption values during cruising [1], are available for the Japanese wheel-onrail system $\mathrm{N} 700$.

\section{PRESENTATION AND CLASSIFICATION OF THE RESULTS}

Energy parameters for different railway systems can be determined with high accuracy using simulation calculations. Simulation methods allow train operation profiles, including the electric drive and power calculations by specifying the operation, route, vehicle and drive system configurations. These simulations also allow appropriate plausibility checks for railway systems. The specific energy consumption values mentioned in this article are based mainly on simulation results. Typical application-specific speed profiles, which essentially consist of the driving states of acceleration, cruising and retardation/braking, are taken into account. In particular, the acceleration and braking processes that have significant impact on the 
energy parameters of the systems are taken into account. Owing to poor information availability for some systems, it is also necessary to use static calculations for constant speed (so-called cruising) and adapt it computationally if other reliable data are not available. Based on the graphical representation of these data, bandwidths can be determined for the specific energy consumption of High-Speed systems depending on the approach.

The conventional approach based on 'energy consumption per seat and kilometre' will be amended in chapter 5 to include a new, more practical representation based on the actual system-typical effective area of High-Speed railway systems. The criterion of effective area can enable better retroactive computation and a more realistic mathematical comparison of different technologies and systems.

\subsection{Basis of the comparison}

Since absolute energy consumption representations may apply only for specific trips with a specific train configuration, and the transport capacity of the railway systems in question may significantly differ from one another, the question is how to compare without much distortion. Firstly, a representation commonly used in the industry is shown.

One usual, conventional form of representation is to compare the energy consumption values per seat and for one-kilometre distance depending on the speed.

Such a conventional comparison commonly used in industry is, however, not considered sufficient from the perspective of the authors, as it is strongly dependent on individual operating requirements such as comfort and mixing ratio - the number of seats can be compared in almost any configuration, which influences almost any statement on energy consumption per seat. For example, the decision alone regarding the sizes of the 1st class and 2nd class sections calculated for the systems being considered has a considerable effect on the subsequent result of the comparison [15].

Therefore, the authors have chosen a new form of representation: comparing the specific energy consumption with respect to the system-typical effective area of the railway systems and a 1-km distance based on speed. They feel this approach provides a significantly better method of representation without much distortion.

The comparison of the energy consumption is made at the medium voltage level in the substation, for example, $15 \mathrm{kV}$ in the ICE $3 / 20 \mathrm{kV}$ in the Transrapid system. Different measuring points/interfaces are marked accordingly. 
The basic setup of the power supply and drive structure of the Wheel-Rail systems and Maglev systems based on the long stator motor technology (Transrapid, Chuo Shinkansen) is shown in Fig. 1. Whereas all the drive components are inside the vehicle in the Wheel-Rail system, the main drive components such as the route cable system, switching points and long stator winding are arranged along the track or directly on the track in the case of the Maglev system.

The project-specific design of track-side infrastructure has a significant influence on operational performance and flexibility, the equipment costs, the energy parameters of the system, and therefore the energy costs in the case of the long stator system. In a Wheel-Rail system, the performance data and efficiency curves of the drive system are defined largely by the train configuration regardless of the route.

The specific energy consumption values were calculated under various boundary conditions (vehicle configurations, route characteristics, average distance between stations, and technical system design for the Maglev system). With this information, the specific energy consumption values from various project plans were used especially for the Maglev system, which are based on different technical system designs of the drive and power supply components. Specifying boundary conditions allows a range of energy consumption values to be determined (see section 6).
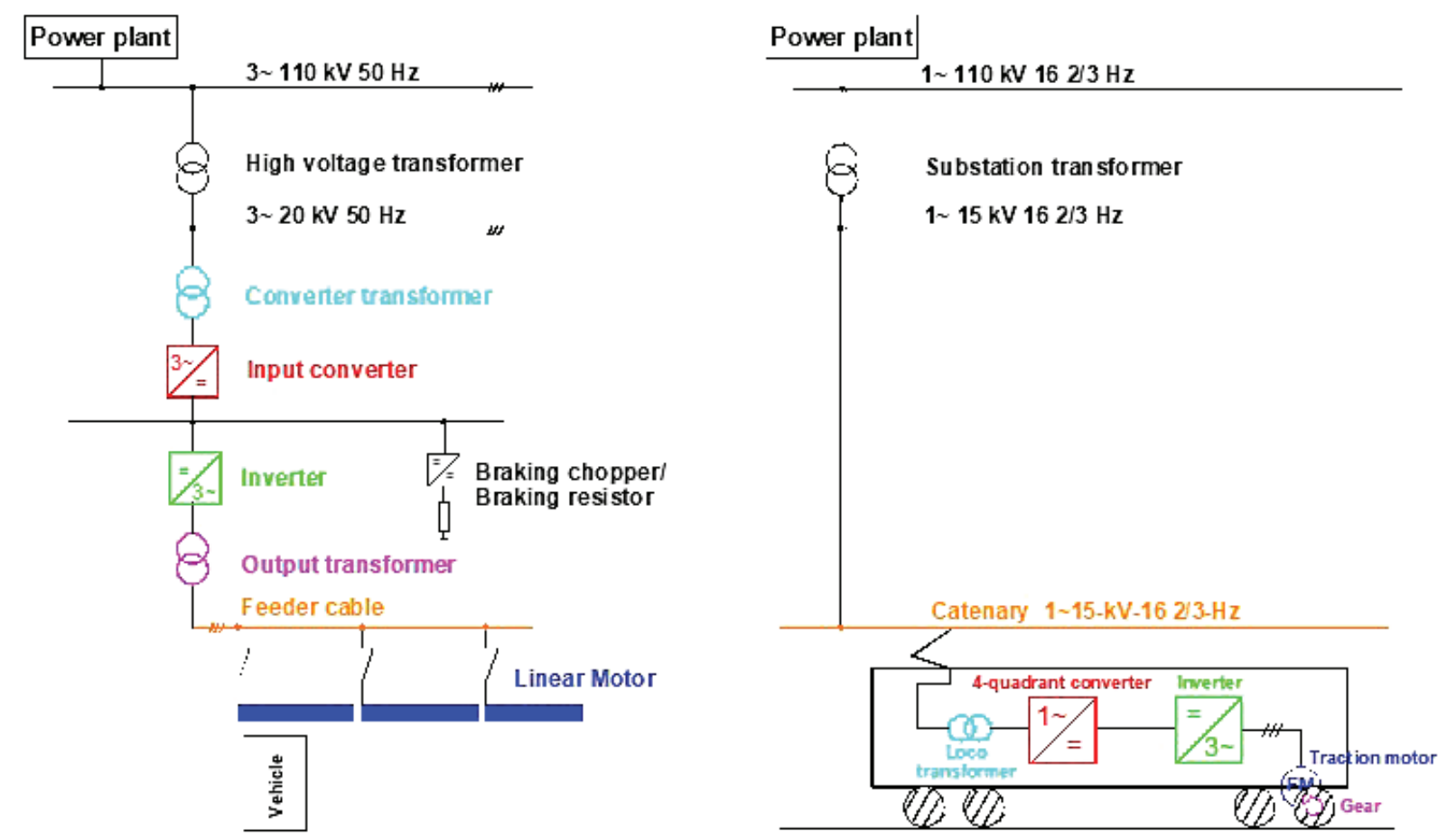

Fig. 1. Basic setup of the energy supply structure for the Maglev system (long stator) and for the wheel-on-rail system with the respective interfaces 


\subsection{Comparison of driving resistances}

An important factor for the energy consumptions of High-Speed railway systems is the driving resistance, or the resistance that has to be overcome by the system for vehicle movement.

Driving resistance consists of the vehicle resistance, the track resistance and acceleration resistance.

- The vehicle resistance is crucial for the energy consumption, especially in the upper speed range. This includes rolling resistance (linear function of the weight), the air resistance (linear function of the speed) and the aerodynamic driving resistance (quadratic function of speed) in the case of the Wheel-Rail system. In the case of Maglev system, the vehicle resistance consists of the linear generator resistance (depending on the decoupled power and speed), the Eddy current resistance (socalled 'magnetic roller friction') and the aerodynamic driving resistance (quadratic function of speed);

- The track resistance depends on the gradients and bending (sag and crest) of the track;

- The acceleration resistance is proportional to the vehicle weight and acceleration.

The following Fig. 2 shows the vehicle resistances of the HSR systems being studied for specific train configurations having similar seating capacities.

What is notable here is the very high resistance of the Chuo Shinkansen [1] at $100 \mathrm{~km} / \mathrm{h}$, which is due to the large magnetic resistance of an EDS system (electro-dynamic system) at the beginning of levitation (the system is still supported on wheels up to about $100 \mathrm{~km} / \mathrm{h}$ ).

\section{SPECIFIC ENERGY CONSUMPTION ON A CONVENTIONAL BASIS (SEAT-KM)}

The Japanese Shinkansen N 700 records the maximum value for WheelRail systems at speeds up to $300 \mathrm{~km} / \mathrm{h}$. At a constant speed of $300 \mathrm{~km} / \mathrm{h}$, it has a specific energy consumption of $28 \mathrm{Wh} / \mathrm{Pl} / \mathrm{km}$ (Watt hours per seat and per kilometre) [1]. With this driving condition of constant inertia (speed), the energyintensive acceleration processes of a typical speed profile are missing. For real N 700 speed profiles with a maximum speed of $285 \mathrm{~km} / \mathrm{h}$ [14], the mean specific energy consumption is about $70 \mathrm{Wh} / \mathrm{Pl} / \mathrm{km}$ in spite of a comparatively high number of seats $(1,123$ seats in 16 cars and 546 seats in 8 cars $[6,7])$, which is therefore higher than the comparable values of other systems at $300 \mathrm{~km} / \mathrm{h}$, and which would again be higher at $300 \mathrm{~km} / \mathrm{h}$ for the $\mathrm{N} 700$. 


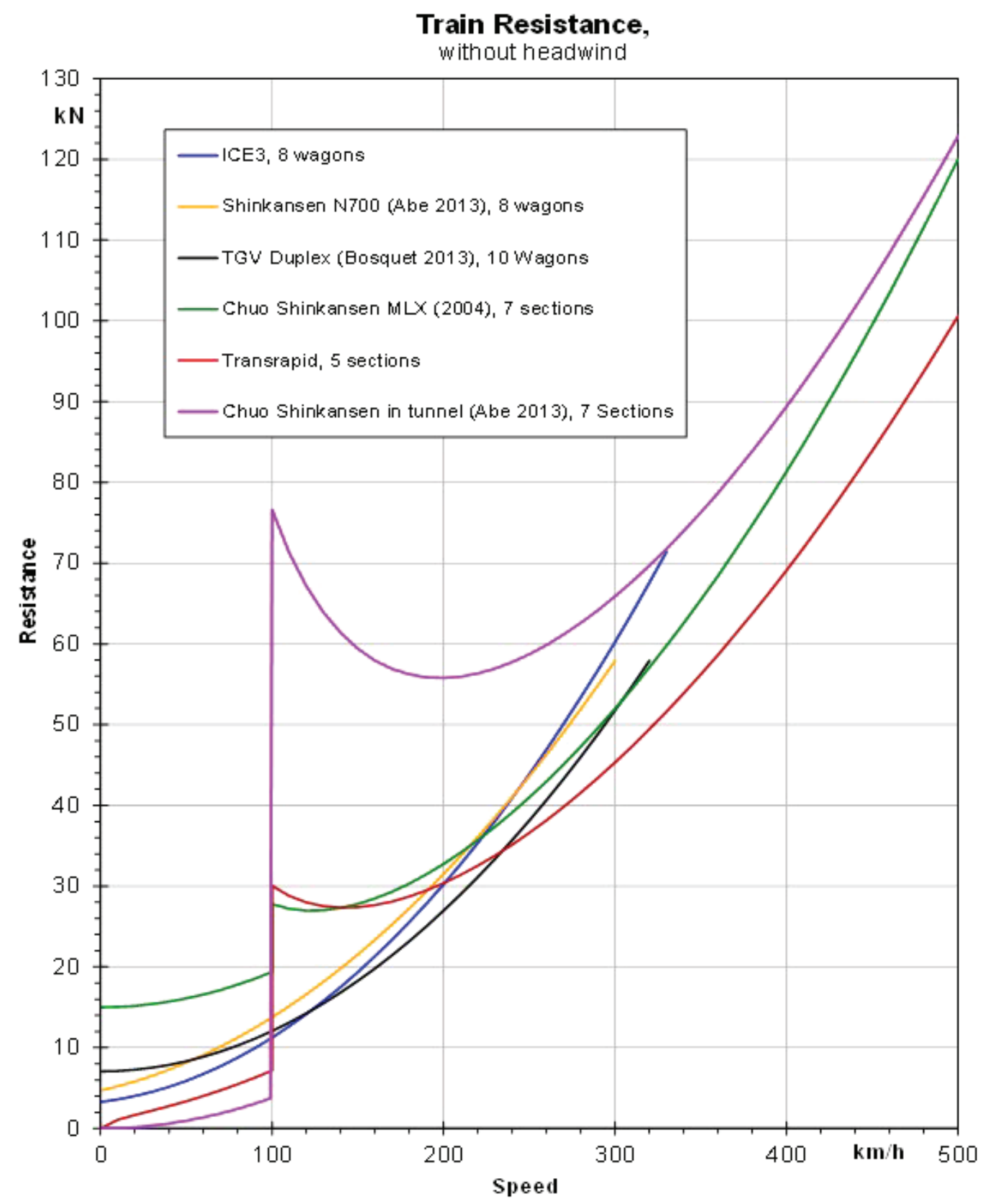

Fig. 2. Driving resistance curves of the considered Wheel-Rail and Maglev systems on an open-air section

Fig. 3 shows the specific secondary energy consumption of the considered systems with reference to 1 seat and a $1-\mathrm{km}$ distance $(\mathrm{Wh} / \mathrm{Pl} / \mathrm{km})$ depending on the respective maximum speed.

If Maglev systems are operated with short vehicles (e.g., TR with 3 sections), then the drive efficiency is reduced compared to trains with 5 or more sections, depending on the system. In the case of simultaneous use on routes with short distances between stations, and consequently many acceleration and braking sections in the total speed profile, relatively high specific energy consumption values are 


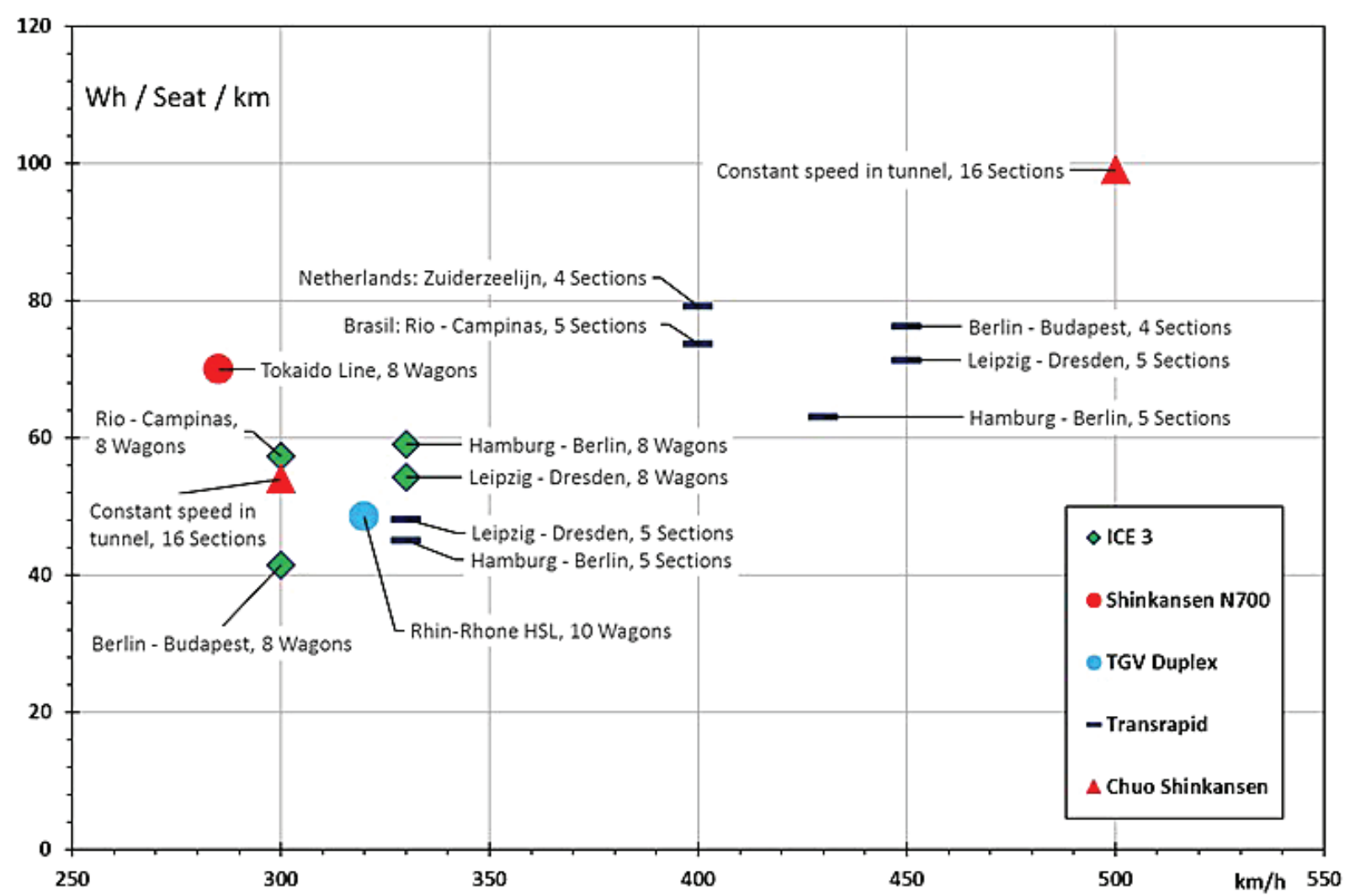

Fig. 3. Conventional representation:

Specific energy consumption of the HRS systems being considered per seat-km $(\mathrm{Wh} / \mathrm{Pl} / \mathrm{km})$ based on the projects under study. Note on distortion: Different vehicle sizes and seat numbers are being compared. The speed range below $250 \mathrm{~km} / \mathrm{h}$ is not shown

expected, as shown in the Zuiderzeelijn project (average distance between stations about $20 \mathrm{~km}$ [13]). High specific energy consumption values are also expected for routes that are topographically challenging, as in the Rio de Janeiro (sea level) Campinas route (685 $\mathrm{m}$ above sea level [12]).

The comparison of the energy consumption values at $330 \mathrm{~km} / \mathrm{h}$ is shown in the following Fig. 4 separately for different Wheel-Rail and Maglev systems. At this maximum speed, the Transrapid (5 section vehicle Hamburg - Berlin route) has the lowest energy consumption with $45 \mathrm{Wh} / \mathrm{Pl} / \mathrm{km}$, and the ICE 3 has the highest energy consumption on the same route with $59 \mathrm{Wh} / \mathrm{Pl} / \mathrm{km}(+31 \%$ compared to Transrapid). It is worth noting here that the Transrapid has just a $7 \%$ higher energy consumption at $430 \mathrm{~km} / \mathrm{h}(+30 \%$ higher max. speed) with $63 \mathrm{Wh} / \mathrm{Pl} / \mathrm{km}$ than the ICE at $330 \mathrm{~km} / \mathrm{h}$ on the same route.

For long stator systems, it is also necessary to take into account that the synchronous internal voltage (reverse voltage), which varies with the weight, and therefore with the typical system effective area, is not proportional to the power and the energy consumption. The aspect of internal voltage therefore has to be 


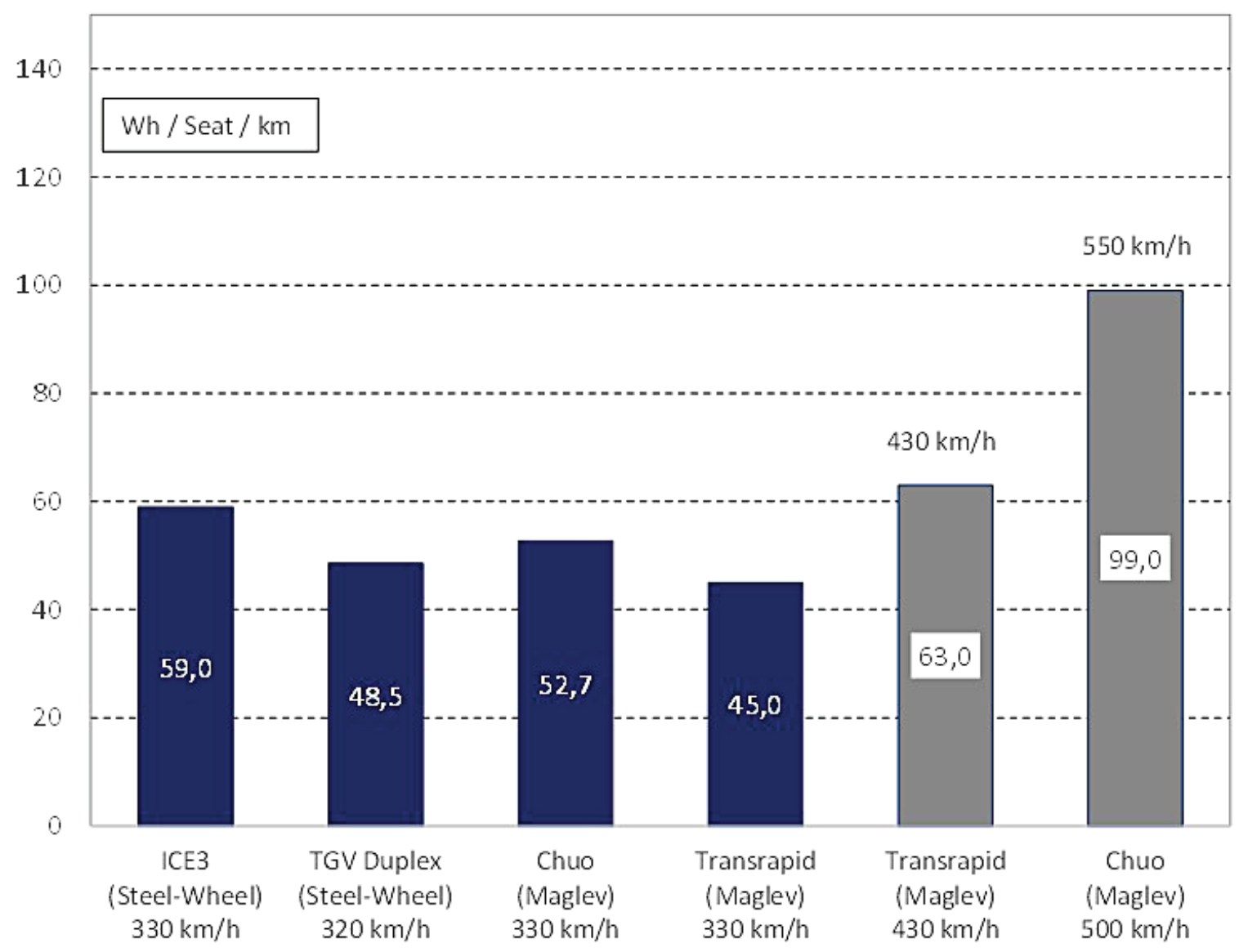

Fig. 4. Specific energy consumption in Wh per seat-km (Wh/P1/km) at 330, 430 and $500 \mathrm{~km} / \mathrm{h}$ (conventional representation)

properly determined when calculating the specific energy consumption based on a standardised area, assuming a certain train/vehicle configuration.

For the Japanese Maglev system Chuo Shinkansen, the specific energy consumption at a cruising speed of $300 \mathrm{~km} / \mathrm{h}$ in the tunnel is $54 \mathrm{Wh} / \mathrm{Pl} / \mathrm{km} \mathrm{[1].}$ This value is in the same range as values for the ICE 3, based on speed profile simulations. It must be pointed out that the aerodynamic resistance coefficients increase, especially when going through tunnels, as compared to open-air routes, which inevitably leads to higher energy consumption values for all railway systems.

The energy consumption values of the two Maglev systems, Transrapid and Chuo Shinkansen, on an open-air route are comparable at a maximum speed of $450 \mathrm{~km} / \mathrm{h}$ - Transrapid with $76 \mathrm{Wh} / \mathrm{Pl} / \mathrm{km}$ (Berlin - Budapest route [11]) and $71 \mathrm{Wh} / \mathrm{Pl} / \mathrm{km}$ (Leipzig - Dresden route [4]) and Chuo Shinkansen with $78 \mathrm{Wh} / \mathrm{Pl} /$ $\mathrm{km}$. The specific energy consumption of $99 \mathrm{Wh} / \mathrm{Pl} / \mathrm{km}$ mentioned by S. Abe [1] is significantly higher for the Chuo Shinkansen at a cruising speed of $500 \mathrm{~km} / \mathrm{h}$ in the tunnel, based on the Tokyo-Osaka route. This high value is essentially due to the increase in driving resistance, which increases by 15 to $20 \%$ from $450 \mathrm{~km} / \mathrm{h}$ 
to $500 \mathrm{~km} / \mathrm{h}$ on an open-air route (Fig. 2). Moreover, the additional aerodynamic driving resistance component due to the tunnel route assumes considerably higher values that need to be overcome by the drive system. Based on the information available for the Japanese Maglev system, it is assumed that most of the route (approx. $80 \%$ ) is through the tunnel, and the higher values are therefore realistic.

\section{SPECIFIC ENERGY CONSUMPTION ACCORDING TO TYPICAL SYSTEM EFFECTIVE AREA (NEW APPROACH)}

To answer the question of how energy consumption depends on operating speed for a system with standardised effective area for a specific High-Speed railway system (TGV, ICE, Shinkansen, Transrapid or Chuo Maglev), the seatbased approach is not adequate, as the available effective area also depends on the technology used. The previous approach based on 'Wh per seat and kilometre' will therefore be amended and extended to include a new, more practical representation based on the actual system-typical effective area of High-Speed railway systems.

\section{APPROACH}

- The first step is to define and calculate the system-typical effective areas of the different systems under consideration (section 5.1);

- The second step is to standardise the results mathematically to a common reference: an effective area of $500 \mathrm{~m}^{2}$ (section 5.2).

\subsection{Definition of 'system typical effective area'}

Railway systems can be distinguished based on the ratio of basic technical area (length $\mathrm{x}$ width, in $\mathrm{m}^{2}$ ) to the effective area. To determine the effective area, all the technical areas required by the system - and essential for the system operation have to be deducted from the basic technical area.

In the case of Wheel-Rail trains, the essential system areas at present are the driver's cabs; in the case of automated Maglev systems, e.g., the unusable areas of the crash zones, the (empty) driver cabs or the technical installations in the interior. In contrast to these technical system installations (and their respective space requirement), air conditioning systems, restaurant kitchens, sanitary equipment, 
etc., form part of optional installations, are omitted, because they can be configured based on the choice of the operator.

The calculation of system-typical effective areas of the High-Speed railway systems being considered is shown in Table 1 as defined below:

Table 2. Definition of system-typical effective area of High-Speed railway systems

\begin{tabular}{|c|c|c|}
\hline \multicolumn{3}{|c|}{ Effective area calculation } \\
\hline $\begin{array}{c}\text { ICE, TGV, } \\
\text { Shinkansen } N 700\end{array}$ & $\begin{array}{c}\text { TR } 08 \\
\text { (Maglev) }\end{array}$ & $\begin{array}{c}\text { Chuo Shinkansen } \\
\text { Maglev LO }\end{array}$ \\
\hline $\begin{array}{l}\text { Calculated basic area } \\
\text { minus driver cab areas and } \\
\text { crash zones. Restaurant cars are } \\
\text { considered as passenger cars }\end{array}$ & $\begin{array}{l}\text { Calculated basic area } \\
\text { minus driver cab areas and } \\
\text { crash zones in the two bow } \\
\text { sections }\end{array}$ & $\begin{array}{l}\text { Calculated basic area } \\
\text { minus areas for } 16 \mathrm{~m} \text { bow } \\
\text { section projections, and } \\
\text { minus areas of interior } \\
\text { fittings for magnetic coils } \\
\& \text { shielding }\end{array}$ \\
\hline $\begin{array}{l}\text { - } \mathrm{ICE}=538 \mathrm{~m}^{2} \\
\text { - } \mathrm{TGV}=533 \mathrm{~m}^{2} \\
\text { calculated like ICE } 3 \\
\text { - } \mathrm{N} 700=627 \mathrm{~m}^{2}\end{array}$ & $\begin{array}{l}- \text { TR } 08=331 / 423 \mathrm{~m}^{2} \\
\text { (depends on configuration, } \\
\text { see table } 1 \text { ) }\end{array}$ & $\begin{array}{l}\text { - } 156 \text { to } 660 \mathrm{~m}^{2} \text { (depends } \\
\text { on configuration, see } \\
\text { table } 1)\end{array}$ \\
\hline $\begin{array}{l}\text { Sources: } \\
\text { - TGV Duplex Dasye }[8] \\
\text { - Shinkansen N } 700[5,16] \\
\text { - ICE 3: Manufacturer details }\end{array}$ & $\begin{array}{l}\text { Sources: } \\
\text { [4] and manufacturer details }\end{array}$ & $\begin{array}{l}\text { Sources: } \\
{[1,2,3]}\end{array}$ \\
\hline
\end{tabular}

An alternative criterion of comparison, which may specifically appear to be useful for freight transport applications, is the energy consumption per tonne and kilometer depending on the speed. However, this criterion is not used in this study because we are considering passenger traffic and not the transport of heavy loads, as in container transport. None of the established High-Speed railway systems is designed for transporting heavy goods. However, transport of light goods or mail transport is possible.

\subsubsection{Effective area and seating density of the chuo shinkansen maglev LO}

To clarify the available data (based on Japanese sources [1,2,3] an overview of the values determined for the Maglev L0 is first shown in Table 3, because this system appears to be the least scientifically documented.

The actual available effective area of the Maglev L0 is reduced by about one quarter, based on the assumptions measured at technical basic area of the Maglev LO. 
Table 3. Effective area and seating density of the Chuo Shinkansen Maglev LO

\begin{tabular}{|l|c|c|c|c|c|c|c|}
\hline & $\begin{array}{c}\text { Length } \\
\text { in } \mathbf{~ m}\end{array}$ & $\begin{array}{c}\text { Width } \\
\text { in } \mathbf{~ m}\end{array}$ & $\begin{array}{c}\text { = Basic } \\
\text { area in } \mathbf{~ m}^{\mathbf{2}}\end{array}$ & $\begin{array}{c}\text { Effective } \\
\text { area in } \mathbf{~ m}^{2} \\
\text { calculated }\end{array}$ & Seats & $\begin{array}{c}\text { Minimum } \\
\text { seats } \\
\text { calculated }\end{array}$ & $\begin{array}{c}\text { Maximum } \\
\text { seats } \\
\text { calculated }\end{array}$ \\
\hline $\begin{array}{l}\text { Bow section } \\
\text { (BS) }\end{array}$ & 28 & 2.9 & 81.2 & about 50 & 24 & 24 & 24 \\
\hline $\begin{array}{l}\text { Middle car } \\
\text { (MW) }\end{array}$ & 24.3 & 2.9 & 70.47 & about 56 & 58 to 68 & 58 & 68 \\
\hline $\begin{array}{l}10 \mathrm{MW} \\
+2 \mathrm{BS}\end{array}$ & 299 & 2.9 & 867.1 & about 660 & $\begin{array}{c}604 \\
\text { to } 704\end{array}$ & 628 & 728 \\
\hline
\end{tabular}

\subsection{Comparison of railway systems by system typical effective area}

\subsubsection{Energy consumption of the wheel-rail systems based on system typical effective area}

For realistic clearances of $\mathrm{N} 700$ with a maximum speed of $285 \mathrm{~km} / \mathrm{h}$ [14], the specific energy consumption is $60 \mathrm{Wh} / \mathrm{m}^{2} / \mathrm{km}$ with respect to the typical system effective area. This is partly much higher than the values of comparable WheelRail systems at $300 \mathrm{~km} / \mathrm{h}$ : ICE 3 routes Berlin - Budapest $\left(35 \mathrm{Wh} / \mathrm{m}^{2} / \mathrm{km},[11]\right)$ and Rio - Campinas (51 Wh/m²/ $\mathrm{km}[12])$.

\subsubsection{Energy consumption of the maglev systems based on system-typical effective} area

When comparing the Maglev systems at a maximum speed of $330 \mathrm{~km} / \mathrm{h}$, as well as at $450 \mathrm{~km} / \mathrm{h}$, the values are almost the same for the Japanese and the German system (see Table 4). The very high and constant value of the Japanese system at $500 \mathrm{~km} / \mathrm{h}$ is mainly due to the high aerodynamic resistance in tunnels, in addition to the high driving resistance of the vehicle.

Table 4. Energy consumption of the Maglev systems, calculated based on system-typical effective area for different applications

\begin{tabular}{|c|c|c|c|c|}
\hline & $\begin{array}{c}\text { Leipzig - } \\
\text { Dresden } \\
\mathbf{3 3 0} \mathbf{~ k m} / \mathbf{h}\end{array}$ & $\begin{array}{c}\text { Leipzig - } \\
\text { Dresden } \\
\mathbf{4 5 0} \mathbf{~ k m} / \mathbf{h}\end{array}$ & $\begin{array}{c}\text { Berlin - } \\
\text { Budapest } \\
\mathbf{4 5 0} \mathbf{~ k m} / \mathbf{h}\end{array}$ & $\begin{array}{c}\text { constant } \\
\mathbf{5 0 0} \mathbf{~ k m} / \mathbf{h}\end{array}$ \\
\hline $\begin{array}{c}\text { Chuo } \\
\text { Shinkansen }\end{array}$ & $51 \mathrm{Wh} / \mathrm{m}^{2} / \mathrm{km}$ & $75 \mathrm{Wh} / \mathrm{m}^{2} / \mathrm{km}$ & - & $112 \mathrm{Wh} / \mathrm{m}^{2} / \mathrm{km}$ \\
\hline TR 08 & $51 \mathrm{Wh} / \mathrm{m}^{2} / \mathrm{km}$ & $75 \mathrm{Wh} / \mathrm{m}^{2} / \mathrm{km}$ & $83 \mathrm{Wh} / \mathrm{m}^{2} / \mathrm{km}$ & - \\
\hline
\end{tabular}


In general, it can be seen that the energy consumption values across systems (based on the typical system effective area) become similar when compared to the specific energy consumption values based on the number of seats. Fig. 5 illustrates this situation.

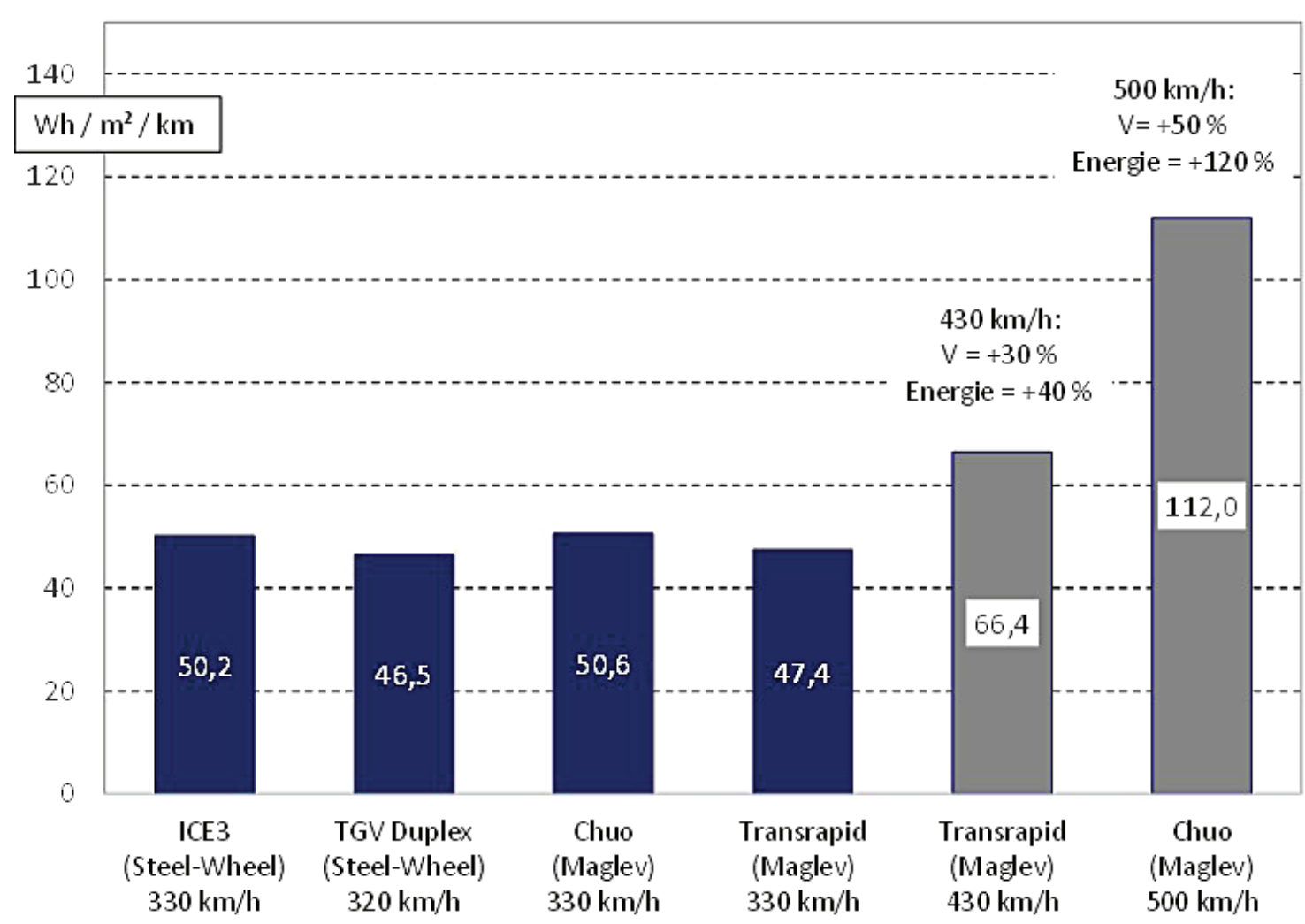

Fig. 5. Specific energy consumption per $\mathrm{m}^{2}-\mathrm{km}$ of system-typical effective area at $330 \mathrm{~km} / \mathrm{h}$ and $500 \mathrm{~km} / \mathrm{h}$

The differences in the energy consumption values between the discussed systems are less than $10 \%$ up to $330 \mathrm{~km} / \mathrm{h}$.

\subsubsection{Interpretation of the results}

None of the considered systems has any significant advantages in terms of energy consumption based on the criteria of effective area. Thus, same-speed energy consumption is therefore not a relevant criterion for any decision for or against a certain high speed railway system.

Project- and operator-related specifications, such as seating densities and the mix of 1st and 2nd class, are not considered when determining the specific energy consumption based on the effective area. Fig. 6 shows the calculated results of the specific energy consumption based on the respective effective area for several 


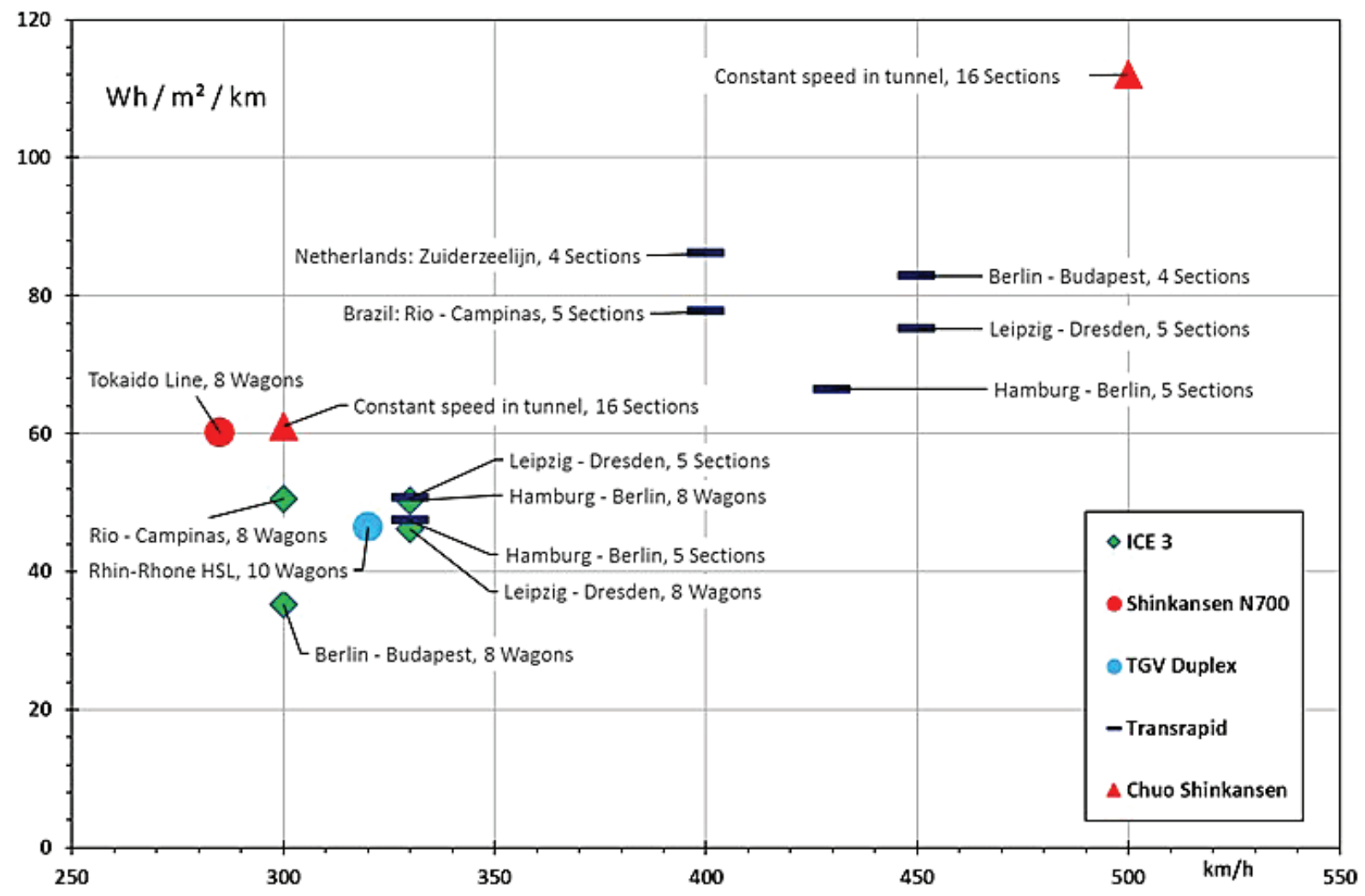

Fig. 6. Specific energy consumption of the HSR systems being considered in Wh per $\mathrm{m}^{2}-\mathrm{km}$ (system typical effective area) for various applications (projects). Comment: The speed range under $250 \mathrm{~km} / \mathrm{h}$ is not shown here for purposes of better readability

applications. From the authors' point of view, this is a more realistic and therefore preferable approach compared to the conventional method.

\subsection{System comparison based on a calculated standardised effective area}

To compare the HSR systems being considered on the same system-typical effective area, the energy consumption values are based on $500 \mathrm{~m}^{2}$ of the systemtypical effective area per vehicle for all systems. This value was chosen by taking into account the system-typical effective area of the systems in this study (see the summary in Table 1).

Fig. 7 shows the specific energy consumption of various HSR systems based on a typical system effective area of $500 \mathrm{~m}^{2}$ per system at a maximum speed of $330 \mathrm{~km} / \mathrm{h}$, taking into account the above-mentioned inherent property of the long stator drive system. This representation now allows statements about the specific energy consumption for different railway systems with a system-typical effective area of $500 \mathrm{~m}^{2}$. For the applications shown in Fig. 7, the specific energy consumption 


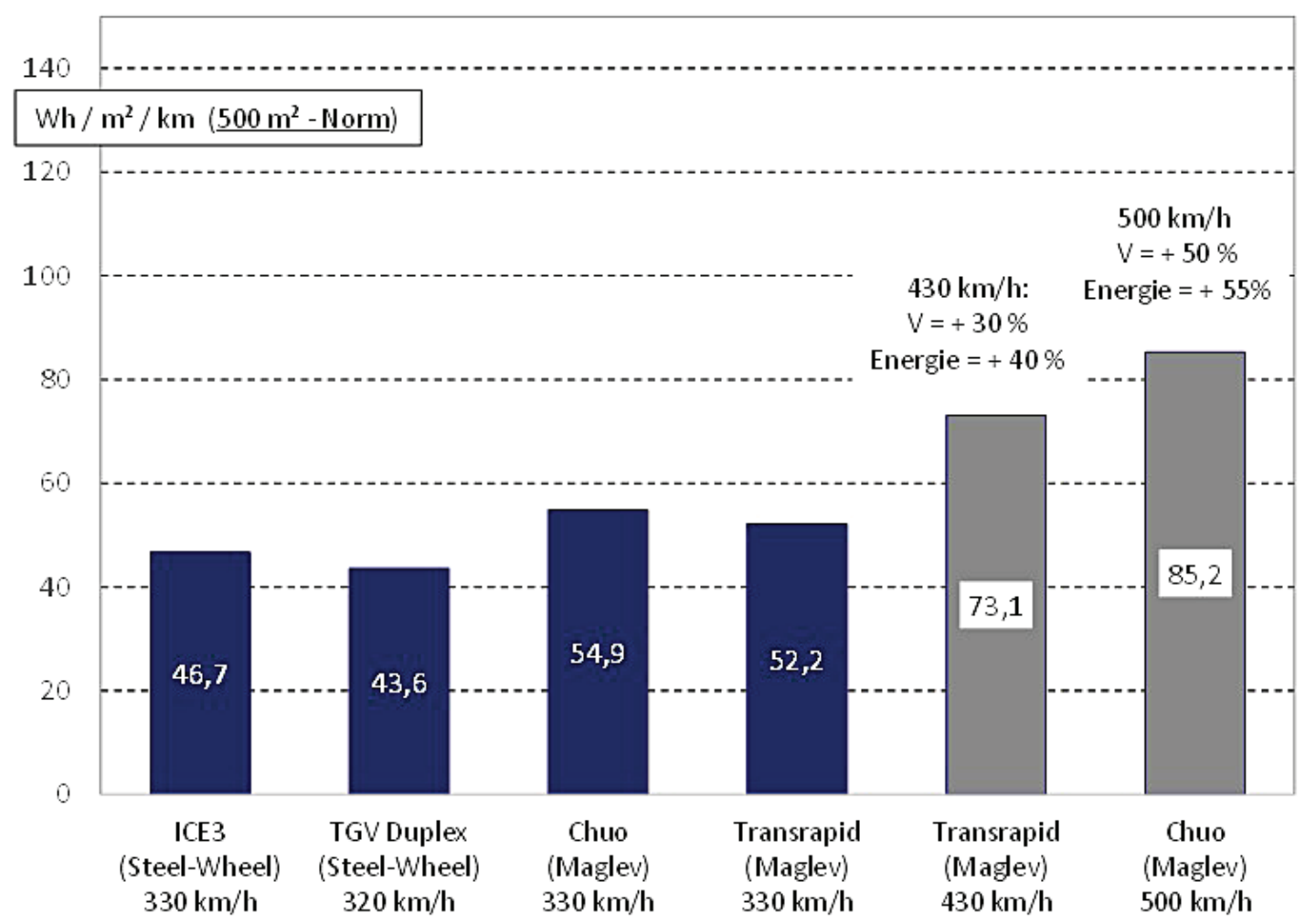

Fig. 7. Specific energy consumption per $\mathrm{m}^{2}-\mathrm{km}$ at $330 \mathrm{~km} / \mathrm{h}$ to $500 \mathrm{~km} / \mathrm{h}$, calculated for a typical system effective area of $500 \mathrm{~m}^{2}$ per system

of the HSR systems are comparable between $45 \mathrm{Wh} / \mathrm{m}^{2} / \mathrm{km}$ and $55 \mathrm{Wh} / \mathrm{m}^{2} / \mathrm{km}$. The long stator systems have an approximately 10-15\% higher specific energy consumption than the comparable Wheel-Rail systems $(330 \mathrm{~km} / \mathrm{h})$.

The specific energy consumption for different applications can also be calculated in $\mathrm{kWh} / \mathrm{km}$ based on a standardised system-typical effective area of railway systems $\left(500 \mathrm{~m}^{2}\right)$ :

Table 5. Specific energy consumption in $\mathrm{kWh} / \mathrm{km}$ for standardised effective area of $500 \mathrm{~m}^{2} \mathrm{per}$ system, mathematical comparison for different applications

\begin{tabular}{|l|c|c|}
\hline & Application being considered & $\begin{array}{c}\text { Average specific energy } \\
\text { consumption }\end{array}$ \\
\hline Transrapid & Hamburg - Berlin, $330 \mathrm{~km} / \mathrm{h}$ & $26 \mathrm{kWh} / \mathrm{km}$ \\
\hline Transrapid & Hamburg - Berlin, $430 \mathrm{~km} / \mathrm{h}$ & $36 \mathrm{kWh} / \mathrm{km}$ \\
\hline Transrapid & Leipzig - Dresden, $450 \mathrm{~km} / \mathrm{h}$ & $41 \mathrm{kWh} / \mathrm{km}$ \\
\hline Chuo Shinkansen & Leipzig - Dresden, $330 \mathrm{~km} / \mathrm{h}$ & $27 \mathrm{kWh} / \mathrm{km}$ \\
\hline Chuo Shinkansen & Tokyo - Nagoya - Osaka, $500 \mathrm{~km} / \mathrm{h}$ & $85 \mathrm{kWh} / \mathrm{km}(\mathrm{cruising})$ \\
\hline ICE 3 & Hamburg - Berlin, $330 \mathrm{~km} / \mathrm{h}$ & $23 \mathrm{kWh} / \mathrm{km}$ \\
\hline TGV Duplex & Rhine - Rhone, $320 \mathrm{~km} / \mathrm{h}$ & $22 \mathrm{kWh} / \mathrm{km}$ \\
\hline
\end{tabular}


Due to the strong project-specific and design-specific influences on the energy consumption, particularly in case of the Maglev systems, the results shown in Fig. 7 and Table 5 cannot be generalized for other applications. Nevertheless, the specific data derived can be used as a reference for estimating the energy consumption values for comparable projects with the same levels of speed.

\subsubsection{Results}

By referring to the already mentioned incomplete information and uncertainties, the considered High-Speed railway systems can be mathematically compared based on a standardised effective area (here: $500 \mathrm{~m}^{2}$ ). The results are the best possible approximation to reality with the mentioned restrictions.

Further detailed representations may be possible only if the respective manufacturers and operators of High-Speed railway systems provide additional, verifiable technical parameters of the railway systems or energy consumption data from implemented applications for scientific analyses.

\section{SUMMARY}

In the past, High-Speed railway systems were often compared based on $\mathrm{Wh} / \mathrm{Pl} / \mathrm{km}$ with regard to their energy consumption. The previously published comparisons could be interpreted in many different ways because the systems being considered have very different characteristics when compared directly (basic area, effective area, or weights). In order to objectively compare railway systems, the comparison should be carried out on a uniform basis. In this study, the comparison was carried out based on the same system-typical effective area. The electrical energy required for operating a high-speed system has been investigated with a standardised effective area depending on the speed, based on a certain High-Speed railway system (TGV, ICE, Shinkansen, Transrapid and Chuo Maglev).

Comparative statements about the specific energy consumption always depend on the route and the application, owing to various system-related properties of the railway systems under consideration. An accurate evaluation of the energy consumption of the systems is only possible when based on the same boundary conditions (route, clearance, maximum speed, vehicle configuration, etc.). However, based on the data available at present, and considering existing information and missing data, the energy consumption of various railway systems can be approximately compared.

For a comparative assessment of the specific energy consumption values of the railway systems being studied, it also makes sense to specify ranges for these 
values. In general, the range of the specific energy consumption increases due to the increase in driving resistance and the associated power consumption, which characteristically increases with the maximum speed. Various other operational and technical design parameters also influence the specific energy consumption.

Based on the existing data, the following ranges are, in principle, available for the specific energy consumption of High-Speed railway systems:

- The specific energy consumption of High-Speed Wheel-Rail systems is in the typical system speed range between 300 to $330 \mathrm{~km} / \mathrm{h}-40 \mathrm{Wh} / \mathrm{Pl} / \mathrm{km}$ (ICE 3) and $70 \mathrm{Wh} / \mathrm{Pl} / \mathrm{km}(\mathrm{N} 700)$ or between $35 \mathrm{Wh} / \mathrm{m}^{2} / \mathrm{km}(\mathrm{ICE} 3)$ and $60 \mathrm{Wh} / \mathrm{m}^{2} / \mathrm{km}$ (N 700);

- The specific energy consumption of the Maglev systems Transrapid and MLX/Chuo Shinkansen is in the speed range from $330 \mathrm{~km} / \mathrm{h}$ to $500 \mathrm{~km} / \mathrm{h}$ - between $45 \mathrm{Wh} / \mathrm{Pl} / \mathrm{km}$ (TR) and $100 \mathrm{Wh} / \mathrm{Pl} / \mathrm{km}$ (Chuo) or between $50 \mathrm{Wh} / \mathrm{m}^{2} / \mathrm{km}$ (TR) and $110 \mathrm{Wh} / \mathrm{m}^{2} / \mathrm{km}$ (Chuo);

- Based on a calculated standardised system-typical effective area of $500 \mathrm{~m}^{2}$ per railway system, specific energy consumption values between $22 \mathrm{kWh} / \mathrm{km}$ (TGV) and $27 \mathrm{kWh} / \mathrm{km}$ (Chuo) are obtained for the railway systems being studied at a maximum speed of $330 \mathrm{~km} / \mathrm{h}$;

- Based on a calculated standardised system-typical effective area of $500 \mathrm{~m}^{2}$ per Maglev system, specific energy consumption values between $36 \mathrm{kWh} / \mathrm{km}$ (TR) and $85 \mathrm{kWh} / \mathrm{km}$ (Chuo) are obtained for the Maglev systems in the speed range between 430 to $500 \mathrm{~km} / \mathrm{h}$.

\section{CONCLUSION}

This comparison of High-Speed railway systems shows that if the same speed range up to $330 \mathrm{~km} / \mathrm{h}$ is considered, none of the systems being studied shows significant advantages in terms of energy consumption. At this designed speed, which is currently the limit of a reasonable operational application of Wheel-Rail systems, there are slight advantages in terms of energy consumption, at least for the Transrapid. In addition, only High-Speed Maglev systems can be operated economically at significantly higher speeds.

Since the Japanese Maglev system between Tokyo and Nagoya is almost entirely operated along a tunnel route, the energy consumption for the ChuoShinkansen system is considerably higher due to the very high tunnel resistance in the High-Speed range when compared to the previous Transrapid projects, which were mostly elevated or ground-level routes without long tunnel sections.

On the whole, this study shows that High-Speed Maglev systems can be objectively considered to be operationally advantageous and useful transport 
systems from the perspective of energy consumption, especially in the area of High-Speed transport exceeding $300 \mathrm{~km} / \mathrm{h}$. If the objective is to reduce travel time and thereby achieve a high speed of a transport system, then High-Speed Maglev systems represent a promising option from an energy consumption point of view, which should always be included in the planning stage of railway projects.

From the perspective of the authors, the planning of High-Speed routes is therefore complete, future-oriented and non-discriminatory only if all the possible railway system options are considered. A system decision, which is also based on the power or energy related aspects, should be open to different technologies and should therefore include High-Speed Maglev systems right from the beginning.

\section{REFERENCES}

1. エネルギー問題としてのリニア新幹線 [Abe Sh. Linear Shinkansen as energy problem. Science (KAGAKU). 2013;83(11):1290-1300. (In Japanese)].

2. 超電導リニアの新型車両の概要について. [JR Central (Tokai). Press Release 26 Oct 2010. (In Japanese)].

3. リニア。あっさり「50 0キロ」突破、摇れは...「地上最高 速」体. [Mainichi Shinbun: 22 September 2014. (In Japanese)].

4. IFB - Institut für Bahntechnik. Comparison of vehicle dynamics and energy consumption of track-based electrical transport systems. IFB-Report No.: 04/511400/241-1, 2004, unpublished.

5. JTB Publishing. The Shinkansen Type book. 2016, 344 p.

6. 電車編成表(2009夏). [Tankan JR, JRR, May 2009, ISBN 9784-330-06909-8. (In Japanese)].

7. 電車編成表(2010夏). [Tankan JR. JRR, May 2010, ISBN 9784-330-14310-1. (In Japanese)].

8. Bosquet R, Vandanjon P, Coiret A, Lorino T. Model of High-Speed Train Energy Consumption. In World Academy of Science, Engineering and Technology. 2013;7(6):767771.

9. German Federal Ministry of Transport, Building and Housing. LCC System Comparison Study: Dornier Consulting. 2003.

10. IFB - Institut für Bahntechnik. TU Berlin: Energy consumption of the Transrapid and ICE 3 railway systems Hamburg - Berlin. IFB-Report No.: 98/BeB/82, May 1998, unpublished.

11. Sächsisches Staatsministerium des Innern. Comparative studies of High-Speed systems in the transport corridor of Berlin - Saxony - Prague - Vienna - Bratislava - Budapest. Final report SIC! - Module: IPE, TU Dresden, IFB - Institut für Bahntechnik GmbH, Obermeyer Albis-Bauplan GmbH, March 2007.

12. IFB - Institut für Bahntechnik: TAV Brasil, Campinas - São Paulo - Rio de Janeiro, Review of operational and economic results, IFB - Report No.: 509310, Sep 2010, unpublished.

13. Dutch Ministry of Transport. Feasibility study Maglev Amsterdam-Groningen "Zuiderzeelijn": Dornier Consulting, 2006. 
14. 特集新しい新幹線を創り出す技術 [Shikoku N. Acceleration of Tokaido Shinkansen and Central Shinkansen by the Superconducting Linear. Nihon Kikai Gakkai Shi. Japanese Machinery Academic Conferences Journal. 2017;170. (In Japanese)].

15. Klühspies J. Future aspects of European mobility. Perspectives and limits of innovative Maglev systems. Köln; 2008.

16. Japan Rail West [Internet]. Shinkansen Nozomi 700 type: Seat layout map. Available at https://www.jr-odekake.net/train/nozomi_700/seat.html. 18 Dec 2017.

Information about the authors:

Fritz Eckert, Dipl.-Ing.;

ORCID: 0000-0003-3422-227X;

E-mail: ef@bahntechnik.de

Blow Larry, B. Sc.;

E-mail: larry@maglevtransport.com

Klühspies Johannes, Prof. Dr. habil. Dr. h.c., full Professor;

ORCID: 0000-0001-6089-9853;

E-mail: jok@maglevboard.net

Kircher Roland, Dr., Dipl-Phys.;

ORCID: 0000-0002-8807-8915;

E-mail: rk@maglevboard.net

Witt Michael H., Dipl-Wi.-Ing.;

E-mail: mikewitt@t-online.de

\section{To cite this article:}

Blow L, Fritz E, Kircher R, Klühspies J, Witt M. Energy Consumption of Track-Based HighSpeed Trains: Maglev Systems in Comparison with Wheel-Rail Systems. Transportation Systems and Technology. 2018;4(3 suppl. 1):134-155. doi: 10.17816/transsyst201843s1134-155 